\title{
Application of lean healthcare in hospital services: a review of the literature (2007 to 2017)
}

\author{
José Daniel Rodrigues Terra ${ }^{\mathrm{a} *}$, Fernando Tobal Berssaneti ${ }^{\mathrm{a}}$ \\ aUniversidade de São Paulo, Escola Politécnica, Departamento de Engenharia de Produção, São Paulo, SP, Brasil \\ *daniel.terra@usp.br
}

\begin{abstract}
Paper aims: The demand for quality health services is increasing and the efficiency in hospitals is related to the continued improvement in their processes and services. Faced with this problem, this study aimed to perform a literature review of the application of lean health care to hospital services.
\end{abstract}

Originality: Link between theory and practice, helping health professionals in their routine.

Research method: The concepts of bibliometrics were used. The databases that make up the sample are ISI Web of Science, Scopus, Lilacs, PubMed, and Cinahl; all the articles were in the ISI Web of Science database.

Main findings: The analyses suggest that the continuous improvement in processes and in the quality of the services offered are factors that influence the development of teams concerned with patient safety.

Implications for theory and practice: Shows the results and difficulties encountered by hospitals with the implementation of lean methodologies.

\section{Keywords}

Bibliometric. Lean health care. Planning lean health care management. Hospital services.

How to cite this article: Terra, J. D. R., \& Berssaneti, F. T. (2018). Application of lean healthcare in hospital services: a review of the literature (2007 to 2017). Production, 28, e20180009. https://doi.org/10.1590/0103-6513.20180009

Received: Feb. 8, 2018; Accepted: June 3, 2018.

\section{Introduction}

Process reengineering methodologies have become an international management phenomenon (Waring \& Bishop, 2010), as there have been a growing pressure on health services to increase their efficiency. To achieve this goal, health services have sought alternatives to traditional models, adopting methodologies for improving processes commonly used in the manufacturing sector, including lean manufacturing (Radnor et al., 2012).

The lean methodology, originated at Toyota, and also known as the Toyota Production System (TPS), is considered a radical alternative to the traditional mass-production model. Lean is defined as a methodology that adopts the elimination of waste, as well as the aggregation of value to all processes, whose goal is to improve the final product (Brackett et al., 2013) and to maximize operational efficiency, quality, speed and cost of operations (Holweg, 2007).

The lean approach finds popular appeal in health care as it seeks to redesign clinical practices and resources around simplified, efficient and value-added care (Waring \& Bishop, 2010).

The approach adopted in health systems is different from that adopted in manufacturing systems, since the processes are different, particularly for working with human lives. Thus, the definition of lean for health systems has different interpretations and practices, and is commonly called lean health care.

Nelson-Peterson \& Leppa (2007) state that lean health care is neither an adapted manufacturing tactic nor a cost reduction program; it is a management strategy based on process improvement in a system. Radnor et al. (2012) 
claim that it is a management practice based on the philosophy of continuously improving processes, reducing activities of little or no value added to the patient, variation in processes and precarious working conditions.

Lean promotes a structured approach to problem solving and improvement efforts linked to hospital strategy (Mazzocato et al., 2012). It illustrates the desire of policy makers to reorder clinical work by introducing managerial philosophies and techniques, involving the systematic evaluation of the existing work process to determine the evidence of its waste and inefficiencies, increasing productivity and efficiency according to the new evidence (Waring \& Bishop, 2010).

The lean methodology for hospitals focuses on key processes, and aims to improve and standardize processes, increase patient efficiency and satisfaction, and decrease unnecessary resources (Vats et al., 2012). This places lean principles at the heart of patient-oriented strategies (MacFarlane, 2014).

Health professionals need to be aware that lean helps in process improvement and value stream mapping, offering many opportunities for health organizations and their ongoing improvement initiatives (Vats et al., 2012). When applied correctly, they help assess the value of each step in the process, as well as measure and identify the variation of a process for conducting positive and repeatable results (Vats et al., 2011).

Radnor et al. (2012) identify three key aspects for the lean methodology to be introduced in a hospital: the evaluation of existing processes, the adoption of improvements in processes and the monitoring of performance of the improvements implemented. Mazzocato et al. (2010) add to the need and willingness to improve organizational performance, creating alternative solutions and increased team communication.

Waring \& Bishop (2010) say that management should emphasize creating value streams and reducing waste, leading to the reconfiguration of clinical practices to produce more productive and value-added processes.

Eliminating unnecessary steps in a process improves patient productivity, quality, and flow. To eliminate waste, process changes are required (Toussaint, 2009). The application of lean principles has created conditions that enable health professionals to perform their functions without wasting or, in a minimized way, increasing patient satisfaction (Nelson-Peterson \& Leppa, 2007).

To materialize the potential benefits of lean, organizations need to minimize the impact of barriers and make specific conditions available to the local context (Mazzocato et al., 2012). In a hospital, the work of multidisciplinary teams is also important for the methodology to be well accepted.

The resources available, the involvement of doctors and managers indicate and affect the strategic importance and, therefore, the opportunity to change (Andersen et al., 2014).

The transformation of the quality system must be part of a comprehensive management system, within an institutional culture of support and with committed leadership. Quality improvement specialists do not work in isolation, but in collaboration with operational leaders (Kaplan et al., 2014).

Many clinical leaders motivate teams to develop timely improvements rather than a unified improvement program with other departments or organizational units (Radnor et al., 2012), limiting themselves to adopting specific lean techniques to solve a specific problem within a specific unit or department (Mazzocato et al., 2010). This makes the professionals resist to the changes, reluctant to adopt new working procedures (Nelson-Peterson \& Leppa, 2007).

The way lean methodology is adapted to health care is not fully recognized in the literature (Papadopoulos et al., 2011); it cannot be said that lean works for everyone.

The use of lean in isolated niches of quality improvement is not enough. Transformation requires the use of lean as part of a comprehensive management system together with changing institutional culture and new leadership approaches to all aspects of health care delivery (Kaplan et al., 2014). For implementing the lean methodology, it is essential to know how to identify clients and processes, using clear and appropriate terminology (Proudlove et al., 2008).

Radnor et al. (2012) state that there are two main reasons for the lack of implementation of lean: lack of training - lean is not understood by system actors; lack of incentive of the organization's leadership to conduct lean in a structured way. Few studies are found about lean basics to improve the operations of hospital services (Laganga, 2011).

In this scenario, the implementation of lean methodology in health services has a great impact on the efficiency of hospital processes, acting as a facilitator and / or an inhibitor in the implementation of projects of continuous improvement.

The purpose of this paper is to analyze the literature on the application of lean to hospital services; based on this analysis, to identify the research trends and gaps, the theoretical pillars and the most relevant topics commonly addressed by authors within this area. The study on the development of the theme over time was 
based on a literature review, with the help of bibliometric, which shows the academic evolution of lean health care, from its initial approaches.

\section{Methods}

The methodological approach was the review of the literature, supported by bibliometric and the analysis of networks of relationship between publications. It was thus possible to analyze the development of the theme over the years, identifying the main authors and subjects discussed, as well as contributing to the content evolution.

For Haunschild et al. (2016), bibliometric aims to quantify the result and interconnection of scientific activity, with the number of publications being the measure of production, while the number of citations is the impact indicator, the "measurable" aspect of quality. In addition, it is possible to measure the content by searching keywords, showing the connection between the authors and the subjects studied.

The keywords of the search were: 'lean health care', 'lean health care management' and 'planning lean health care management', all searched with the 'AND' connector. The research was conducted in five different databases: ISI Web of Science, Scopus, Cinahl, Lilacs and PubMed, because of their relevance to the health area. The ISI Web of Science and Scopus databases have filters by 'document type', 'categories' and 'source titles'. The Cinahl database does not have the division by 'categories' and the PubMed and Lilacs databases do not have the division by 'source titles'.

During the filtering process, no filters were used for the criteria 'journals' and 'period of publication'; the objective was to select all articles published by the database until the date of the search.

In 2007, the theme lean health care became relevant to researchers, with a growing number of research. For this reason, this study includes articles in the period that varies between 2007 and 2017.

The initial survey of the sample, considering all articles, resulted in 2788 titles. After analyzing the filters considered, according to the areas of interest and the relevant and impact journals for the research, this number lowered to 853 articles. Of this total, duplicate titles were discarded, only one article per theme being considered. The final base resulted in 670 articles; they had their summaries evaluated, allowing to fit the really relevant articles to the theme, which resulted in 98 articles. Note that the metadata was extracted from the 1SI Web of Science database, since this database has the largest number of articles available. Figure 1 shows the process for selecting the articles.

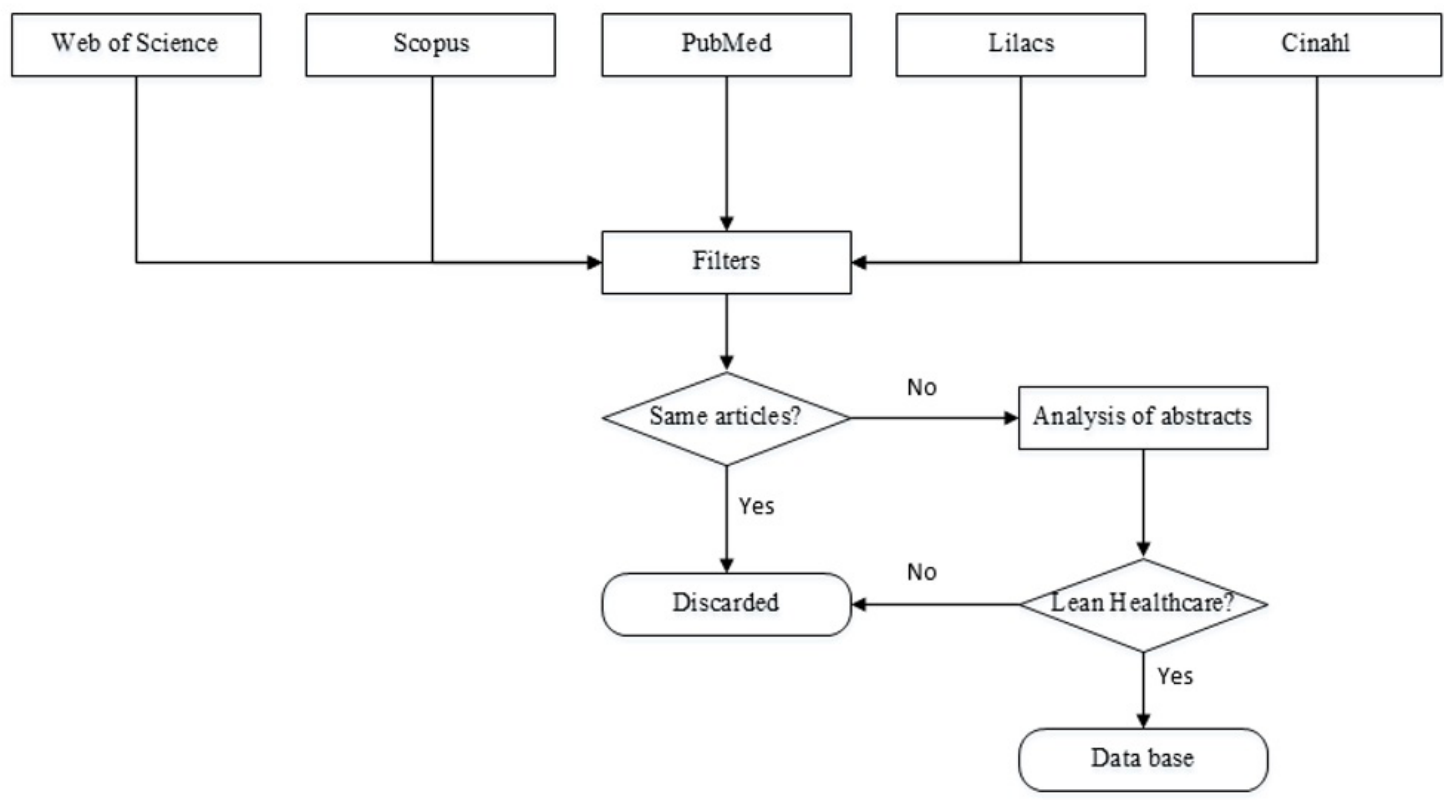

Figure 1. Flowchart for database selection. 
From the selected articles, according to the process shown in Figure 1 and considering the period from 2007 to 2017 , the studies that involved process improvements ( 8 articles), efficiency ( 5 articles) and patient safety (4 articles) had the largest amount of publications. In contrast, articles discussing lean and six sigma have little relevance in the period. Table 1 shows the topics covered in the articles throughout in this period.

Table 1. Subjects covered in the articles, from 2007 to 2017.

\begin{tabular}{|c|c|c|c|c|c|c|c|c|c|c|c|}
\hline $5 S$ & & & & & & & & & 1 & 1 & \\
\hline Add value to services & 1 & 1 & 1 & 3 & & 2 & 1 & & 3 & & 4 \\
\hline Efficiency & & & 1 & 1 & & 2 & 1 & 2 & 3 & 5 & 1 \\
\hline Critical success factor & & & & & & & & & & & 1 \\
\hline Lean and Six Sigma & & & & & & & & & 2 & 1 & 1 \\
\hline Processes improvement & & 1 & 1 & 2 & 2 & 3 & 1 & 3 & 4 & 8 & 5 \\
\hline Organizational improvement & & & & 2 & & 1 & & 3 & 1 & 1 & \\
\hline Quality in services & & & & 2 & 1 & 1 & & 3 & 3 & 2 & \\
\hline \multirow[t]{2}{*}{ Patient safety } & & & & & & 1 & 1 & 1 & 2 & 4 & \\
\hline & 2007 & 2008 & 2009 & 2010 & 2011 & 2012 & 2013 & 2014 & 2015 & 2016 & 2017 \\
\hline
\end{tabular}

Table 2 shows a summary of the search: the filters used in each database, the results achieved from each search and the final result, including articles with repeated themes.

From the complete database, the Bradford Dispersion Law was applied, which shows the relationship between the set of journals used in the database and its productivity, in descending order (Araújo, 2006). In this group, the articles with the highest number of citations were considered, which established the minimum cut in 20 citations per article. This resulted in 13 publications, which accounted for $74 \%$ of the total citations. Table 3 shows a summary of the 13 most important publications and their number of citations.

Haunschild et al. (2016) hold the number of citations is a good indicator of impact. Thus, the 13 most cited articles shown in Table 3 were predominantly considered in the literature. When the sample was selected, the article metadata was imported by the VOSviewer software, version 1.6.4, and the networks were analyzed by the Netdraw software, version 2.161 .

\section{Results}

The characterization of the sample of the publications sought to map the orientation of the articles over the period considered. It is noteworthy that the theme gained significant importance as of 2007, when a greater number of publications began to occur. Thence, the analysis period is from 2007 until the year of the survey, 2017. Figure 2 shows this evolution.

Figure 2 shows that the peak of publications occurred in 2016, with 22 publications, which corresponds to $22.45 \%$ of the total number of publications in the sample. Note that in 2017 , there were 10 publications;

\section{8}

Figure 2. Evolution of the theme over the period (2007 to 2017). 
Table 2. Filters used in the search process in databases.

\begin{tabular}{|c|c|c|c|}
\hline Base & Category & Filter & Result \\
\hline \multirow[b]{3}{*}{  } & $\begin{array}{l}\text { Type of } \\
\text { document }\end{array}$ & Articles & 537 \\
\hline & Category & $\begin{array}{l}\text { Computer science information systems, critical care medicine, industrial engineering, manufacturing engineering, } \\
\text { multidisciplinary engineering, health care sciences services, health policy services, management, medical informatics, } \\
\text { medicine general internal, medicine, research experimental, multidisciplinary sciences, nursing, operations research } \\
\text { management, science, public administration, public environmental occupational health, interdisciplinary social } \\
\text { sciences, surgery. }\end{array}$ & 407 \\
\hline & $\begin{array}{l}\text { Source } \\
\text { titles }\end{array}$ & $\begin{array}{l}\text { American Journal of Medicine, American Journal of Preventive Medicine, American Journal of Surgery, Australian } \\
\text { Health Review, BMC Health Services Research, BMC Medical Informatics and Decision Making, BMC Public Health, } \\
\text { BMC Womens Health, BMJ Open, BMJ Quality Safety, Emergency Medicine, Global Health Action, Health Affairs, } \\
\text { Journal of Health care Engineering, Health Policy, Health care The Journal of Delivery Science and Innovation, } \\
\text { Herd Health Environments Research Design Journal, Internal Medicine Journal, International Journal for Quality in } \\
\text { Health Care, International Journal of Health Care Quality Assurance, International Journal of Health Planning and } \\
\text { Management, International Journal of Health Policy and Management, International Journal of Medical Informatics, } \\
\text { International Journal of Nursing Studies, International, Journal of Operations Production Management, International } \\
\text { Journal of Production Research, International Journal of Productivity and Performance Management, International } \\
\text { Journal of Public Sector Management, International Journal of Quality Reliability Management, Journal for Health } \\
\text { care Quality, Journal of Clinical Nursing, Journal of Health Organization and Management, Journal of Health care } \\
\text { Management, Journal of Medical Systems, Journal of Nursing Administration, Journal of Nursing Management, } \\
\text { Journal of Operations Management, Journal of Pediatric Nursing Care of Children Families, Journal of Service } \\
\text { Management, Journal of Strategy and Management, Leadership in Health Services, Pflege, Plos One, Quality and } \\
\text { Reliability Engineering International, Quality Management in Health Care, Quality Safety in Health Care, Revista } \\
\text { da Escola de Enfermagem da USP, Revista Latino Americana de Enfermagem, Safety Science, Safety Science, Rural } \\
\text { and Remote, Health, Social Science Medicine, Supply Chain Management, The American Journal of Maternal Child } \\
\text { Nursing, Work a Journal of Prevention Assessment Rehabilitation. }\end{array}$ & 160 \\
\hline \multirow[b]{3}{*}{$\stackrel{气}{0}$} & $\begin{array}{l}\text { Type of } \\
\text { document }\end{array}$ & Articles & 719 \\
\hline & Category & $\begin{array}{l}\text { Computer science, decision sciences, engineering, environmental sciences, health professions, medicine, nursing, } \\
\text { social sciences. }\end{array}$ & 433 \\
\hline & $\begin{array}{l}\text { Source } \\
\text { titles }\end{array}$ & 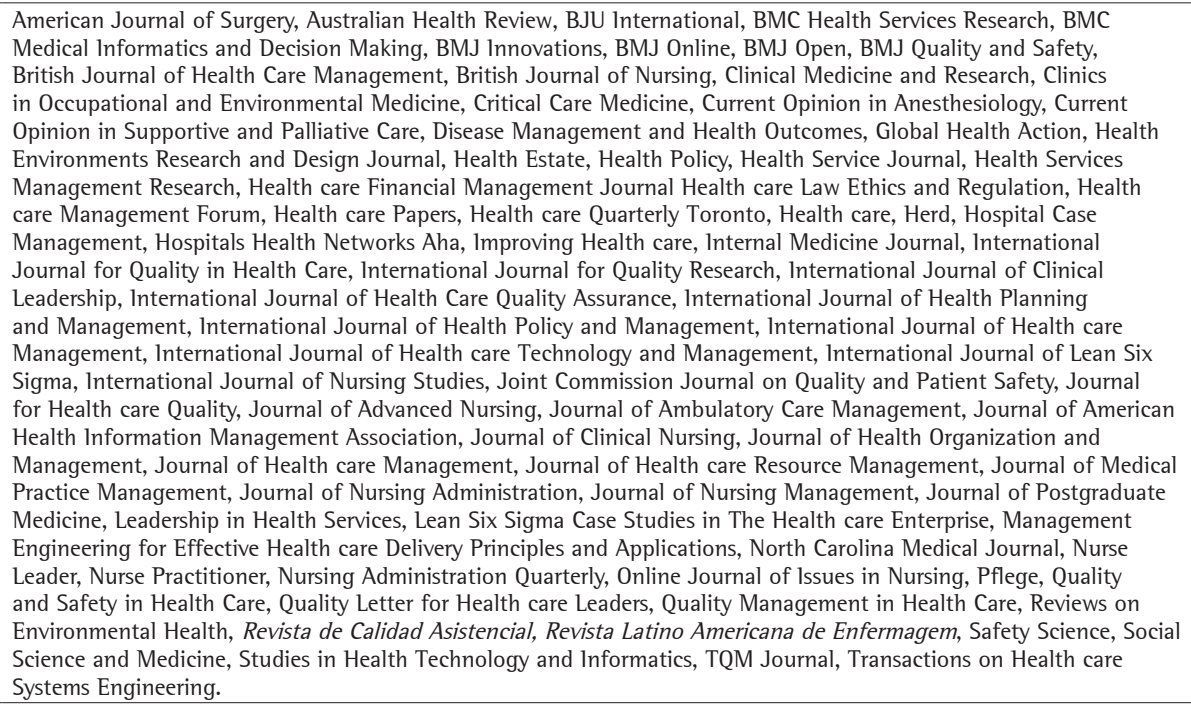 & 234 \\
\hline \multirow[b]{2}{*}{$\begin{array}{l}\bar{E} \\
\stackrel{\widetilde{\pi}}{\Xi}\end{array}$} & $\begin{array}{l}\text { Type of } \\
\text { document }\end{array}$ & Articles & 966 \\
\hline & $\begin{array}{l}\text { Source } \\
\text { titles }\end{array}$ & $\begin{array}{l}\text { American Journal of Occupation \& Therapy, Assistive Technology, Australian Journal of Rural Health, British Journal } \\
\text { of Community Nursing, British Journal of Nursing, Emergency Nurse, Health \& Social Care in the Community, Health } \\
\text { \& Social Work, Health Care for Women International, Integrative Medicine: A Clinician’s Journal, International } \\
\text { Journal of Palliative Nursing, International Journal of Therapy \& Rehabilitation, Journal of Addictions Nursing, } \\
\text { Journal of Alternative \& Complementary Medicine, Journal of Nursing Education, Journal of Occupational } \\
\text { Rehabilitation, Journal of Rehabilitation Research \& Development, Journal of School Nursing, Journal of Social Work } \\
\text { Practice, Journal of The American Academy of Nurse Practitioners, Medsurg Nursing, Nursing \& Residential Care, } \\
\text { Nursing Economic\$, Nursing Management, Nursing Standard, Occupational Therapy International, Online Journal } \\
\text { of Rural Nursing \& Health Care, Pediatric Nursing, Physical Therapy, Scandinavian Journal of Caring Sciences, } \\
\text { Scandinavian Journal of Occupational Therapy, Work \& Stress. }\end{array}$ & 279 \\
\hline \multirow{2}{*}{$\sum_{0}^{\infty}$} & $\begin{array}{l}\text { Type of } \\
\text { document }\end{array}$ & Articles & 400 \\
\hline & Category & Core clinical journals, humans, medline e nursing journals. & 63 \\
\hline \multirow{2}{*}{$\frac{\mathscr{y}}{\stackrel{\pi}{\Xi}}$} & $\begin{array}{l}\text { Type of } \\
\text { document }\end{array}$ & Articles & 166 \\
\hline & Category & Humans & 117 \\
\hline
\end{tabular}


Table 3. Most cited articles, authors and number of citations.

\begin{tabular}{|c|c|c|c|}
\hline Articles & Author & Journal & Citations \\
\hline Lean in health care: The unfilled promise? & Radnor et al. (2012) & Social Science \& Medicine & 112 \\
\hline $\begin{array}{l}\text { Lean thinking in health care: a realist review of the } \\
\text { literature. }\end{array}$ & Mazzocato et al. (2010) & Quality Safe Health Care & 112 \\
\hline Lean health care: Rhetoric, ritual and resistance. & Waring \& Bishop (2010) & Social Science \& Medicine & 70 \\
\hline A critical look at Lean Thinking in Health care. & Young \& McClean (2008) & Quality Safety Health Care & 67 \\
\hline $\begin{array}{l}\text { Creating an Environment for Caring Using Lean } \\
\text { Principles of the Virginia Mason Production System. }\end{array}$ & Nelson-Peterson \& Leppa (2007) & $\begin{array}{l}\text { The Journal of Nursing } \\
\text { Administration }\end{array}$ & 52 \\
\hline $\begin{array}{l}\text { Lean service operations: Reflections and new directions } \\
\text { for capacity expansion in outpatient clinics. }\end{array}$ & Laganga (2011) & $\begin{array}{l}\text { Journal of Operations } \\
\text { Management }\end{array}$ & 45 \\
\hline $\begin{array}{l}\text { Lessons for Lean in Health care from Using Six Sigma } \\
\text { in the NHS. }\end{array}$ & Proudlove et al. (2008) & Public Money \& Management & 36 \\
\hline $\begin{array}{l}\text { The role of actor associations in understanding the } \\
\text { implementation of Lean thinking in Health care. }\end{array}$ & Papadopoulos et al. (2011) & $\begin{array}{l}\text { International Journal of } \\
\text { Operations \& Production } \\
\text { Management }\end{array}$ & 29 \\
\hline $\begin{array}{l}\text { Implementation of releasing time to care - the } \\
\text { productive ward. }\end{array}$ & Wilson (2009) & Journal of Nursing Management & 29 \\
\hline $\begin{array}{l}\text { Lean thinking in hospitals: is there a cure for the } \\
\text { absence of evidence? A systematic review of reviews. }\end{array}$ & Andersen et al. (2014) & BMJ Open & 21 \\
\hline $\begin{array}{l}\text { How does lean work in emergency care. A case study } \\
\text { of a lean inspired intervention at the Astrid lindgren } \\
\text { Children's hospital, Stockholm, Sweden. }\end{array}$ & Mazzocato et al. (2012) & BMC Health Services Research & 21 \\
\hline Why lean doesn't work for everyone. & Kaplan et al. (2014) & Quality Safety Health Care & 20 \\
\hline $\begin{array}{l}\text { Writing The New Playbook For U.S. Health Care: } \\
\text { Lessons From Wisconsin. }\end{array}$ & Toussaint (2009) & Health Affairs & 20 \\
\hline
\end{tabular}

however, the sample was collected in July, which does not allow concluding whether there was a greater or lesser number of publications in 2017 as compared to 2016. From 2007 to 2010, an evolution occurred in this line of research; between 2011 and 2013, the evolution of publications occurred intermittently and from 2014 onwards, a new growth of publications, with an upward trend over the years.

Concerning the issues addressed by the authors in the articles, Table 1 shows that $30.6 \%$ of the articles (30 articles in the sample) discuss process improvement, 16.3\% (16 articles) deal with process efficiency, 12\% (12 articles) deal with quality in services and 16.3\% (16 articles) deal with adding value to services. Considering the point of view of processes and services, $46.9 \%$ of the articles (46 articles) discuss processes and 28.5\% (28 articles) discuss services, totaling $75.4 \%$ of the sample (74 articles) that discuss processes or services. It is noteworthy that only $4.1 \%$ of the sample ( 4 articles) represents studies in the lean and six sigma, a very small portion for such an important subject.

Among the articles selected, the sample highlights there is a great increase in publications in different journals. Totaling 98 publications, 53 articles were published in 11 different journals, corresponding to 54\% of the publications, emphasizing that the subject attracts great interest by journals, although there are few publications; this justifies the study of lean in health care is a very important. Table 4 shows a summary of journals with more publications.

Table 4. Dispersion of publications in journals.

\begin{tabular}{lccc}
\hline \multicolumn{1}{c}{ Journal } & Publications & \% Unitary & \% Accumulated \\
\hline Herd Health Environments Research Design Journal & 7 & 7.143 & 7.143 \\
Journal of Health Organization and Management & 7 & 7.143 & 14.286 \\
International Journal of Health care Quality Assurance & 6 & 6.122 & 20.408 \\
BMC Health Services Research & 5 & 5.102 & 25.510 \\
International Journal of Operations Production Management & 5 & 5.102 & 30.612 \\
Journal of Nursing administration & 5 & 5.102 & 35.714 \\
Journal for Health care Quality & 4 & 4.082 & 39.796 \\
Leadership in Health care Services & 4 & 4.082 & 43.878 \\
Quality Safety in Health care & 4 & 4.082 & 47.960 \\
BMJ Open & 3 & 3.061 & 51.021 \\
BMJ Quality Safety & 3 & 3.061 & 54.082 \\
\hline
\end{tabular}


The qualitative analysis of the publications occurred under the scenario of iterations between the publications, the main authors, the keywords used and the countries with the largest number of publications. We tried to understand the patterns of relationship between the database articles and the main theme, lean health care.

This analysis shows three main theoretical lens influencing lean healthcare and the main authors: Management and Operation, which highlight articles focused on process management, health professionals' management and how lean healthcare influences its activities (Drotz \& Poksinska, 2014; Mazzocato et al., 2014; Morrow et al., 2014; Nelson-Peterson \& Leppa, 2007; Papadopoulos et al., 2011; Seidl \& Newhouse, 2012; Van Lent et al., 2012); Quality, where the articles analyze the quality management and the quality in processes and services stand out (Farrokhi et al., 2015; Grove et al., 2010; Hydes et al., 2012; Kaplan et al., 2014; Mazzocato et al., 2010; Naik et al., 2012; Young \& McClean, 2008) and Services, which identifies articles targeted to the services offered by hospitals (Andersen et al., 2014; Mazzocato et al., 2012; Van Lent et al., 2012).

The place where the studies were published highlights the regions where quality in healthcare systems is at a developed stage and they apply different methodologies.

The approach to determining this network was based on a minimum number of publications per country, 5. England distinctly has a large network of connections. One possible explanation for this is due to the National Health Services (NHS), one of the largest and best-known health systems in the world. Consequently, countries such as Northern Ireland, Wales Scotland and Australia, all of which belong to the United Kingdom, also play a prominent role.

The United States also stands out as the precursor to hospital quality seals in the world through the Joint Commission International $(\mathrm{JCl})$, and has a long tradition of quality health systems. Figure 3 shows the countries with the highest incidence of lean-related publications.

Considering the 13 most cited articles of the sample, the network of relationships between the articles and their references was constructed in order to identify the behavior between the authors and their relationship patterns.

Radnor et al. (2012), despite being one of the most cited articles, with 112 citations, is not in a prominent position, unlike Mazzocato et al. (2010), with the same number of citations (112). One possible explanation for

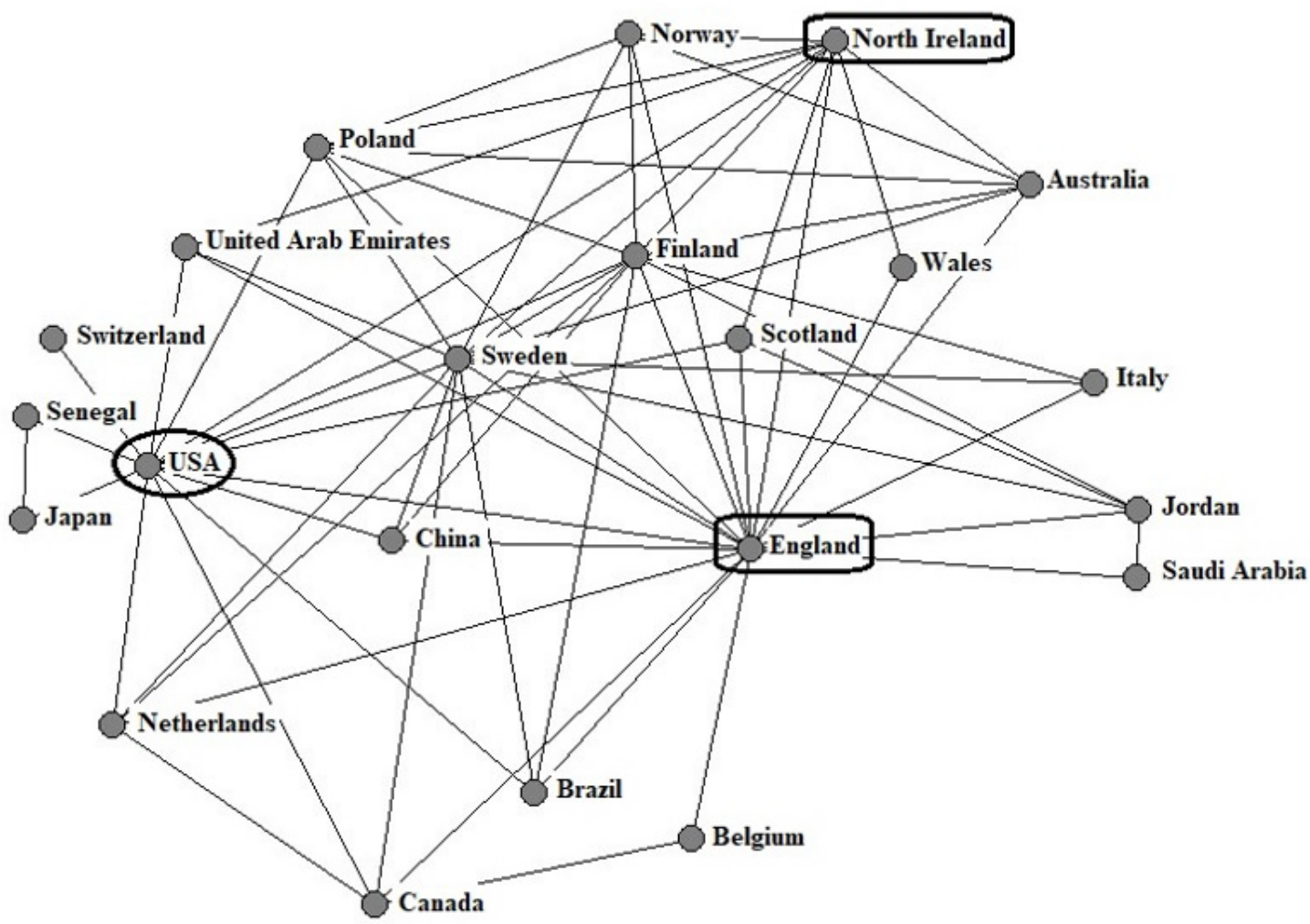

Figure 3. Countries with the largest number of publications on lean health care. 
this may lie in the fact that Mazzocato et al. (2010) is a literature review. In this article, the authors show that lean thinking successfully applied to a wide variety of health settings; although lean emphasizes a holistic view, most reported cases show restricted technical applications with limited organizational reach.

Waring \& Bishop (2010) approach lean health care as a difficult subject to be deployed in hospitals; Young \& McClean (2008) show a critical look at lean health care and its association with other quality methodologies; Nelson-Peterson \& Leppa (2007) refer to a practical application of lean health care.

Figure 4 shows the behavior among the most cited authors, presented in Table 2. It highlights articles with over 50 citations in the database. The authors marked with a rectangle refer to the most cited articles (112 citations each) and those marked with an ellipse refer to the authors who stood out during the search.

The network of the most cited authors and their relations, the degrees of centrality and betweenness stand out. Bordin et al. (2014) state that the degree of centrality shows how much an author relates to other authors, that is, shows the direct and indirect relationship between the published works. The higher this value, the more influential the work of a particular author is.

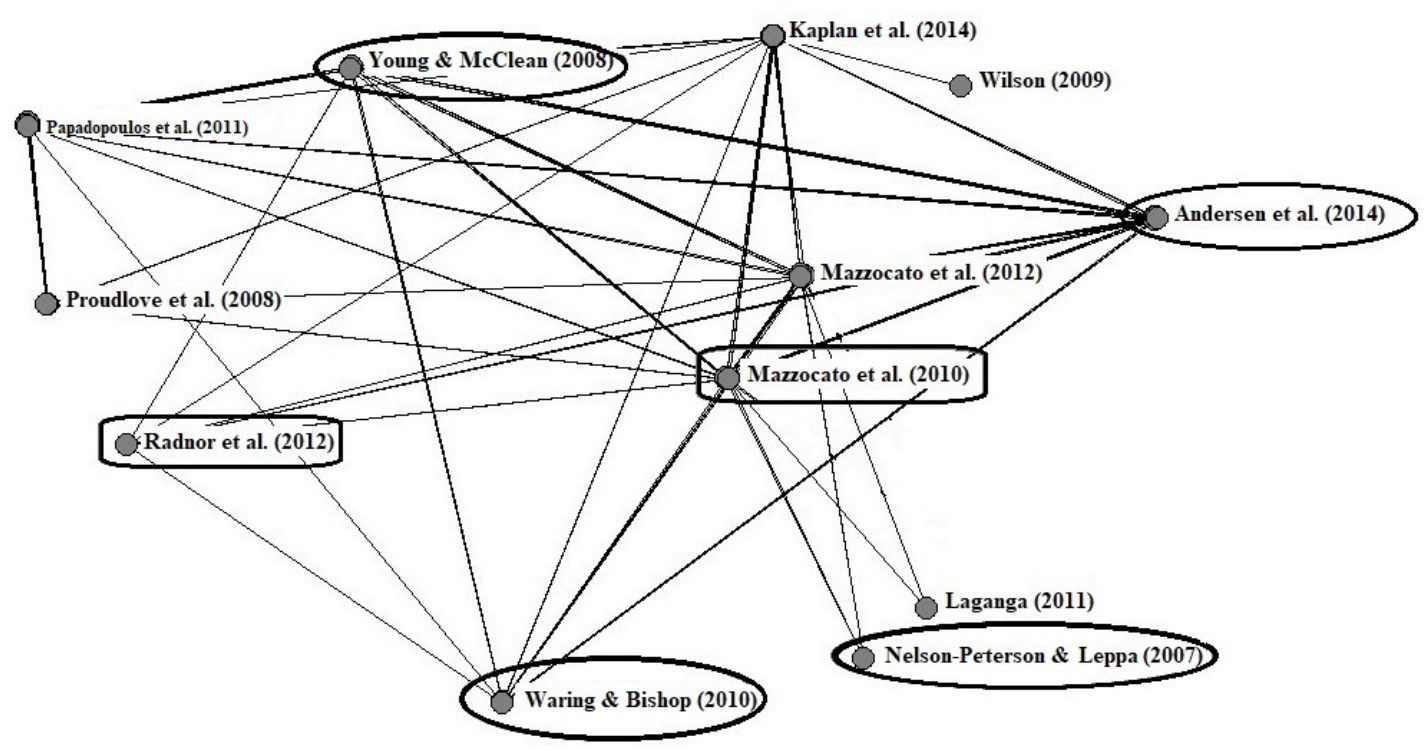

Figure 4. Most cited authors and their relationships.

The degree of intermediation corresponds to how much an article acts as a facilitator of integration with other articles (Lopes \& Carvalho, 2012), it shows how an author is connected with other authors in the network, attributing the importance that this author has in a specific flow of information, characterizing the shortest path possible between the authors (Bordin et al., 2014). This means that the greater degree of betweenness, the more works cited by the related authors, making the cited work become a reference among references. Figure 4 shows that Mazzocato et al. (2012) and Mazzocato et al. (2010) present a large number of connections, making them references in the network of citations. Table 5 shows a summary of these relationships.

The last analysis of the networks deals with the occurrence of keywords, shown Figure 5, where stand out five clusters:

- Lean: addresses the different lines regarding the application of the methodology;

- Six Sigma: addresses the use of the Six Sigma methodology associated with other methodologies;

- Operations: addresses the implementation of proposed methodologies, reengineering and results expected;

- Quality: addresses quality management as a means to achieve the objectives proposed in continuous improvement;

- Institutions: addresses the main actions that institutions adopt to achieve the best results with quality processes. 
Table 5. Centrality degree and Betweenness degree.

\begin{tabular}{lclc}
\hline \multicolumn{1}{c}{ Authors } & Centrality degree & \multicolumn{1}{c}{ Authors } & Betweenness degree \\
\hline Mazzocato et al. (2012) & 138.375 & Mazzocato et al. (2012) & 26.500 \\
Kaplan et al. (2014) & 81.032 & Mazzocato et al. (2010) & 26.333 \\
Mazzocato et al. (2010) & 77.405 & Kaplan et al. (2014) & 25.500 \\
Young \& McClean (2008) & 68.348 & Young \& McClean (2008) & 24.333 \\
Proudlove et al. (2008) & 20.775 & Radnor et al. (2012) & 22.333 \\
Andersen et al. (2014) & 13.443 & Papadopoulos et al. (2011) & 22.333 \\
Radnor et al. (2012) & 5.088 & Waring \& Bishop (2010) & 22.333 \\
Papadopoulos et al. (2011) & 5.088 & Andersen et al. (2014) & 22.000 \\
Waring \& Bishop (2010) & 5.088 & Proudlove et al. (2008) & 19.167 \\
Laganga (2011) & 0.000 & Nelson-Peterson \& Leppa (2007) & 17.500 \\
Nelson-Peterson \& Leppa (2007) & 0.000 & Laganga (2011) & 14.833 \\
Wilson (2009) & 0.000 & Wilson (2009) & 13.167 \\
\hline
\end{tabular}

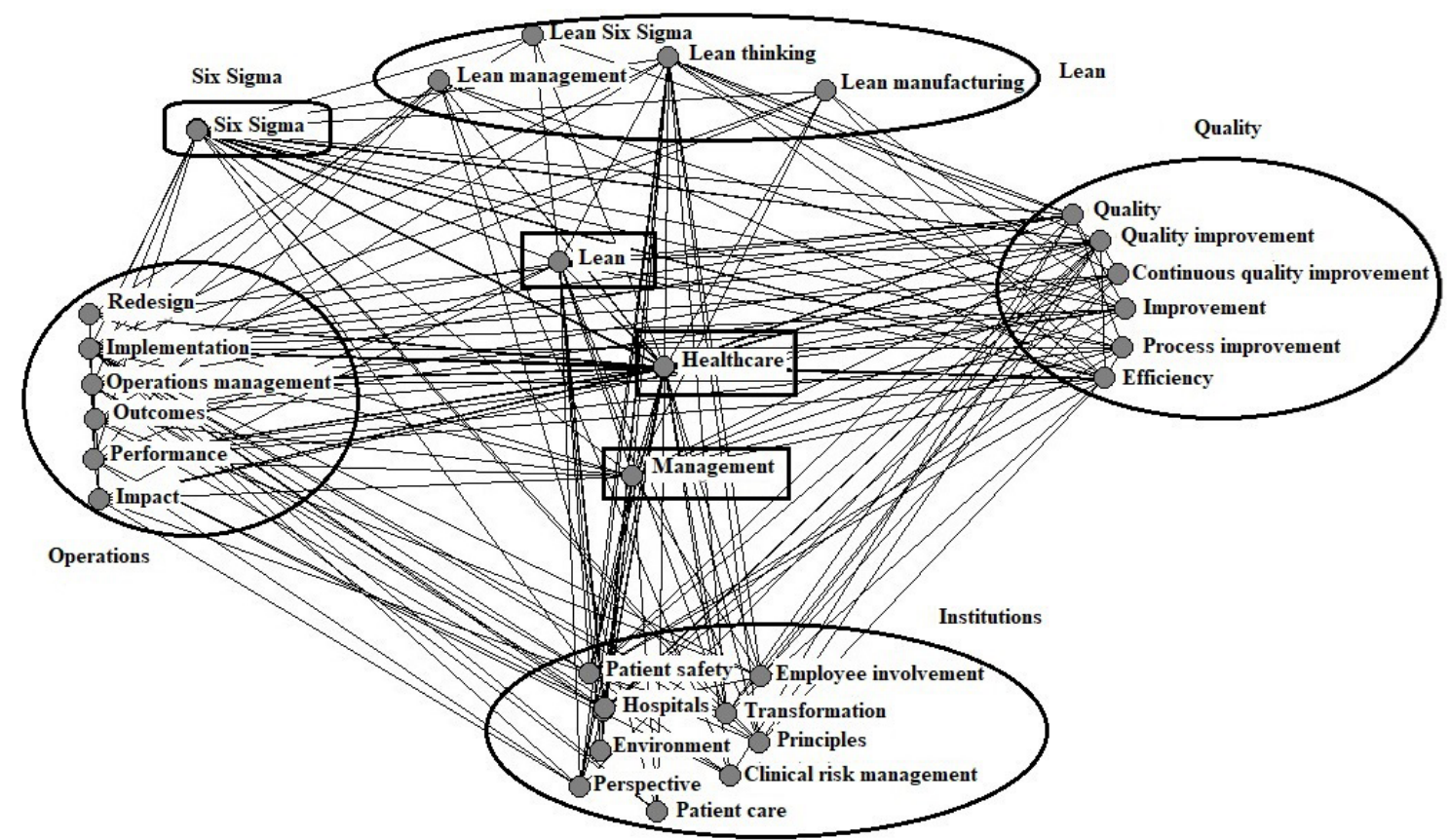

Figure 5. Network of keywords and groupings.

The criterion proposed for cutting was at least five keyword citations within the set of keywords used in all articles. Keywords without meaning, or with generic sense, were discarded, as well as those not recognized, indicated by 'error'. Keywords also have not been considered: lean health care, lean health care management, planning lean health care management.

The application of lean as a methodology for improving quality in health services is essential, since the methodology is approached from different perspectives, according to the need of each institution. Radnor et al. (2012) affirm that a wide variety of specialized management domains are introduced to transform established organizational and professional work practices, considered wasteful, evidencing an increasing impact on quality, cost, time, and satisfaction of both staff and patients.

The keyword 'Six Sigma' has strong association with quality processes, management and operations. This methodology addresses procedures for eliminating or reducing errors in processes and procedures. Although difficult to implement in the service sector, its use has been increasing, especially when associated with other methodologies and quality tools. Here, it appears as an alternative to associate lean tools and procedures. 
The words 'lean', 'health care' and 'management' are centralized in the keyword network. All of them connect with the other clusters and very intensively. The word 'lean' stands out for its connections with the words 'patient safety' and 'employee involvement'. The first is to emphasize the importance of patient safety and the second to validate the importance of patient safety, highlighting the involvement of employees in achieving satisfactory levels of safety.

The word 'health care' emphasizes that operations are paramount to achieve consistent quality health service objectives. The relationship between health care, reengineering, impact, and performance shows that processes influence institution structures; when applied correctly, they produce good performance in quality management.

The word 'management' is the one that has the greatest relationship among all the other words in the network. It is very strongly related to three clusters of the network of keywords: operations, quality and institutions. This word shows that quality management, when associated with the best operations guidelines, is fundamental for health institutions.

\section{Discussion}

According to Table 1, subjects related to processes and services dominate the discussion about lean health care, corresponding to $75.4 \%$ of the articles considered in the study. This is the foundation of kaizen, which aims to continuously improve the culture of the institution, impact on service improvement, reducing waiting times and improving patient care, with more organized spaces and better use and with changes in the flow of processes for workers and patients (Radnor et al., 2012). This shows that the use of lean tools has great insertion capacity, mainly for the continuous improvement of processes.

Figure 2 shows that 2016 was the year with the highest number of publications related to the lean health care subject. Table 4 shows that there is an increase in publications, with a low concentration of journals; 54\% of the publications are in 11 different journals, showing the scope of the subject and the diversity of areas related to the subject.

The two most cited journals, Herd Health Environments Research Design Journal and Journal of Health Organization and Management, have only 7 publications each, resulting in 14.3\% of all the publications. However, of the 856 citations, 634 correspond to the 13 most cited articles, resulting in $74 \%$ of the citations, which shows that few authors dominate the subject, making them the 'gurus' of the theme. This implies that $26 \%$ of the citations are divided among the other 85 articles, many of them with no citations.

Relationship networks play an important role between authors and their works. They show the major influencers in the theme, the countries with the largest number of publications, which encourage carrying out related studies and the connection between the keywords used by the authors.

The social network of countries shows the place where there is a greater concentration of published articles. England stands out for its robust and comprehensive health system, which results in many experiments and, consequently, many articles related to this system. In addition, Figure 3 shows that England has connections with practically all countries, with the exception of Japan, Switzerland, and Senegal. Northern Ireland, which integrates the United Kingdom and has a health care system similar to that of England, also stands out for the number of articles referenced.

In relation to the database, it is important to map the theme in relation to the 13 most cited articles that composed the guiding axis of this work.

The first article relevant to the theme was written by Nelson-Peterson \& Leppa (2007); the authors define lean health care in the Journal of Nursing Administration. In this article, the authors state that the health sector, as occurs with the manufacturing sector, is composed of a series of processes or actions aimed at creating value to patients and that, although there are differences between patients and products, health organizations are complex, with thousands of processes interacting.

This causes hospitals to work towards a good understanding of the patient's needs, requirements or how he interprets a service with high added value, so that there is ambiguity and uncertainty in what should be implemented with Lean (Radnor et al., 2012).

Moraros et al. (2016) corroborate this thinking, stating that lean has expanded to the health sector. The application of specific lean tools, such as kaizen and continuous improvement, tend to produce small and localized productivity gains (Radnor et al., 2012). Their goal was to show that although manufacturing works with different objectives, lean can also be applied to other areas, including health care.

The lean methodology adopts as a precept the importance of value, the search for eliminating waste and adding value to all processes (Brackett et al., 2013). Different tools and methods are used together in a variety 
of settings, generating concepts that create value for patients and healthcare professionals (Mazzocato et al., 2010). Lean simplifies the standardization of tasks, processes, and the reduction of bureaucracy.

Grove et al. (2010) state that the successful deployment of these improvements liberates organization resources, which are redirected to provide direct patient care. Radnor et al. (2012), Seidl \& Newhouse (2012), Mazzocato et al. (2010), Waring \& Bishop (2010) and Nelson-Peterson \& Leppa (2007) corroborate this analysis, as they believe that this generates value to the patient.

Mazzocato et al. (2010) and Radnor et al. (2012) are the articles most cited in the database. Mazzocato et al. (2010) address the issue in the context of a review of the literature, highlighting interventions used in health care, methods for understanding and organizing processes, improving error detection, relaying information to problem solvers, and preventing errors from causing damage and to manage change and solve problems with a scientific approach. In turn, Radnor et al. (2012) highlight the difficulties encountered in the implementation of this methodology in the health sector, as an element of resistance on the part of the professionals involved, reinforcing the results shown by Moraros et al. (2016), Kaplan et al. (2014), Mazzocato et al. (2012) and Waring \& Bishop (2010).

Andersen et al. (2014) emphasize that lean methodology, if not applied properly, does not generate significant results, since this methodology consists of multiple elements that interact with each other. To realize the potential benefits, health organizations need to directly engage top management and seek value creation for patients, nurturing a long-term vision of continuous improvement (Mazzocato et al., 2010).

According to Figure 4, Andersen et al. (2014) have strong connections with Mazzocato et al. (2012), which deal with the problems presented by lean, if not implemented with the necessary resources.

Radnor et al. (2012) emphasize the difficulty in having different working groups interacting in favor of lean implementation. Mazzocato et al. (2010), despite showing lean with a holistic view, in most cases report more restricted technical applications with limited organizational reach. Waring \& Bishop (2010), highlight the difficulties in implementing lean in the health sector and Young \& McClean (2008) emphasize that lean, when applied in isolation, produces little or no significant results. Many approaches are reported as having a punctual impact on quality, cost, time, and patient satisfaction as a single process (Papadopoulos et al., 2011).

The social network of keywords, Figure 5, has density large number of connections between the terms 'lean', 'health care' and 'management' with lean clusters, quality, institutions, operations and six sigma. Essentially, lean health care is a subject matter based on subjectivity between different terms, elements and a certain difficulty in quantitatively measuring the real benefits the methodology can bring to health systems.

However, the occurrence of cluster 'institution' shows that the central terms 'lean', 'health care' and 'management' have strong connection with the words patient safety, hospitals, environment and perspective. This helps to understand the importance of lean health care to institutions, since clusters of 'quality' and 'operations' have strong links to the central terms, forming a tripod that encourages the dissemination of lean methodology in hospital institutions, supported by quality and the way of operations are performed, highlighting improvements to clinical operations that can have a significant effect on patient care, especially in the development of health systems without high-level management of actions (Carter et al., 2012).

The six sigma cluster is related, with greater intensity, to the outcomes of cluster operations, efficiency and quality improvement of cluster quality and transformation of cluster institutions. This indicates that the six sigma methodology is part of the process of continuous improvement, since it directs its efforts to achieve satisfactory results, seeking the efficiency in the quality processes and the transformation in the hospital routines associated to the new established processes. Lean Six Sigma methodology assists hospitals to serve patients better and faster, which in turn will lead to a reduction in treatment delay and faster patient recovery (Gijo \& Antony, 2014).

De Mast et al. (2011) state that the six sigma, lean, and total quality management approaches provide the opportunities needed to identify process improvements from a more accurate diagnosis. For improvement efforts to be successful, promising approaches such as benchmarking and operational research are needed for the selection and application of lean and six sigma factors (Van Lent et al., 2012). Gijo \& Antony (2014) and Van lent et al. (2012) show the relationship between lean and six sigma increase the patient satisfaction.

The connection between lean clusters and institutions shows that hospitals are targeting the improvement of their processes, products and services from the perspective of patient safety. Wilson (2009) says that the lean methodology can improve patient satisfaction and safety-oriented clinical outcomes.

Crema \& Verbano (2015) point out that improvements in patient safety and efficiency associated with lean \& safety projects can be deployed together to improve efficiency and patient safety levels. Contradicting Wilson (2009) and Crema \& Verbano (2015), Moraros et al. (2016) state that lean does not generate the potential benefits in the processes established for patient safety. 
The operations cluster stands out for its connections with the word health care, showing the importance of operations management for health care systems. Drotz \& Poksinska (2014) highlight the importance of teamwork in the organizational environment and personal development, influencing organizational performance. De Mast et al. (2011) maintain that the division of labor into micro processes, tasks, and resources yields a system of metrics for process flow and resource efficiency.

The application of lean health care in hospital services, within a process of interaction with health professionals, shows the relevant difficulties in applying continuous improvement methodologies focused on quality.

\section{Conclusion}

The present study aimed to analyze the literature on lean health care in hospital services, using bibliometric resources. It sought to identify the main elements and aspects related to the proposed theme, as well as research gaps. The descriptive analysis showed an overview of lean health care and the social network analyses showed the main countries that publish on the topic, the relationships between the authors and the main keywords used in the articles of the database.

Within the lean health care research, the term 'management' serves as the central point of connection between three major areas: operations, quality and institutions. Programs that adopt lean health care as a methodology for continuous improvement in products and services need the support of management to implement the methodologies, as they often overcome internal obstacles, both regarding infrastructure and human resources. Mazzocato et al. (2010) state that to improve lean efficacy in health care, it is necessary to involve management in the continued resolution of problems.

For hospital institutions, safety and patient care, coupled with lean perspectives, are critical to its application. However, this perspective can vary, since hospitals have different human resources, which are influenced by different organizational forms.

The team plays a key role in the implementation of lean methodologies. Morrow et al. (2014) reaffirm that the empowerment of the team allows leaderships to continuously disseminate the learning and the sustainability of the improvements. However, Drotz \& Poksinska (2014) warn that lean can change the roles, responsibilities and characteristics of the work of the health team.

In most cases, lean applications emphasize the reduction of waste, since lean is a managerial concept (Radnor et al., 2012; Nelson-Peterson \& Leppa, 2007). However, Table 1 shows that patient safety has increased its influence on the subjects studied, since it directs the focus to the final client.

Future studies may direct their efforts toward the contradiction between the use of lean for managerial factors - which encompasses large multidisciplinary teams, or punctual factors - which comprises specific points of the processes involved. An approach in this line maybe will be interesting.

Acceptance of projects that aim to modify a work structure usually finds strong resistance, where critical success factors in lean projects are determinant for their performance, even if the impact is not significant in all dimensions (Berssaneti \& Carvalho, 2015). Future studies may address the relationship between worker qualification and the use of lean methodologies when evaluating productivity in the health care environment, as well as the relationship with customers and suppliers and the development of systems capable of encouraging process innovation in search for continuous improvement.

The increasing use and dissemination of the internet, relating process data associated with the productivity of health care professionals and the need to manage different types of information, in a short period of time is increasingly present in this universe. In this direction, to study the possible connections between lean methodology and its application in internet of things (loT).

The relationship between quality, costs and time need to be better equated, surpassing the purely qualitative approach. A more careful analysis of these factors would provide greater applicability to lean methodology.

The application of the lean methodology still remains rooted in the improvement of productive processes, associated with products. Future research could go deeper into lean studies, directing it to the service sector, specifically in health care.

The work has some limitations. It cannot be generalized, since the final database included only the articles that were in the ISI Web of Science database; this limitation is a reflection of the software used, VOSviewer, which only accepts files generated by a database.

The identification of the articles pertinent to the theme was made from reading the abstracts of each article; therefore, it cannot be said that the abstracts faithfully expresses the content of the article. 
Some articles may not have been listed in the database because of the difficulty in relating as many keywords as possible. This gives a degree of lack of assertiveness to the full analysis of the topic.

The articles studied do not represent the universality of the theme but only those that were captured by the search for keywords adopted.

\section{References}

Andersen, H., Røvik, K. A., \& Ingebrigtsen, T. (2014). Lean thinking in hospitals: is there a cure for the absence of evidence? A systematic review of reviews. BMJ Open, 4(1), e003873. http://dx.doi.org/10.1136/bmjopen-2013-003873. PMid:24435890.

Araújo, C. A. (2006). Bibliometria: evolução história e questões atuais. Questão, 12(1), 11-32. http://dx.doi.org/10.19132/1808-5245121.

Berssaneti, F. T., \& Carvalho, M. M. (2015). Identification of variables that impact project success in Brazil companies. International Journal of Project Management, 33(3), 638-649. http://dx.doi.org/10.1016/j.jproman.2014.07.002.

Bordin, A. S., Gonçalves, A. L., \& Todesco, J. L. (2014). Análise da colaboração científica departamental através de redes de coautoria. Perspectivas em Ciência da Informação, 19(2), 37-52. http://dx.doi.org/10.1590/1981-5344/1796.

Brackett, T., Comer, L., \& Whichello, R. (2013). Do lean practices lead to more time at the bedside? Journal for Healthcare Quality, 35(2), 7-14. http://dx.doi.org/10.1111/j.1945-1474.2011.00169.x. PMid:22093157.

Carter, P. M., Desmond, J. S., Akanbobnaab, C., Oteng, R. A., Rominski, S. D., Barsan, W. G., \& Cunningham, R. M. (2012). Optimizing clinical operations as part of a global emergency medicine initiative in Kumasi, Ghana: Application of lean manufacturing principals to low-resource health systems. Academic Emergency Medicine, 19(3), 338-347. http://dx.doi.org/10.1111/j.1553-2712.2012.01311.x. PMid:22435868.

Crema, M., \& Verbano, C. (2015). How to combine lean and safety management in health care processes: a case from Spain. Safety Science, 79, 63-71. http://dx.doi.org/10.1016/j.ssci.2015.05.007.

De Mast, J., Kemper, B., Does, R. J. M. M., Mandjes, M., \& Van Der Bijl, Y. (2011). Process improvement in healthcare: overall resource efficiency. Quality and Reliability Engineering International, 27(8), 1095-1106. http://dx.doi.org/10.1002/qre.1198.

Drotz, E., \& Poksinska, B. (2014). Lean in healthcare from employees' perspectives. Journal of Health Organization and Management, 28(2), 177. http://dx.doi.org/10.1108/JHOM-03-2013-0066. PMid:25065109.

Farrokhi, F. R., Gunther, M., Williams, B., \& Blackmore, C. C. (2015). Application of lean methodology for improved quality and efficiency in operating room instrument availability. Journal for Healthcare Quality, 37(5), 277-286. http://dx.doi.org/10.1111/jhq.12053. PMid:24112283.

Gijo, E. V., \& Antony, J. (2014). Reducing patient waiting time in outpatient department using lean six sigmamethodology. Quality and Reliability Engineering International, 30(8), 1481-1491. http://dx.doi.org/10.1002/qre.1552.

Grove, A. L., Meredith, J. O., Macintyre, M., Angelis, J., \& Neailey, K. (2010). Lean implementation in primary care health visiting services in National Health Service UK. Qual Saf Health Care, 19(5), 1-5. PMid:20511600.

Haunschild, R., Bornmann, L., \& Marx, W.. (2016). Climate change research in view of bibliometrics. PLoS One, 11(7), e0160393. http:// dx.doi.org/10.1371/journal.pone.0160393. PMid:27472663.

Holweg, M. (2007). The genealogy of lean production. Journal of Operations Management, 25(2), 420-437. http://dx.doi.org/10.1016/j. jom.2006.04.001.

Hydes, T., Hansi, N., \& Trebble, T. M. (2012). Lean thinking transformation of the unsedated upper gastrointestinal endoscopy pathway improves efficiency and is associated with high levels of patient satisfaction. BMJ Quality \& Safety, 21(1), 63-69. http://dx.doi. org/10.1136/bmjqs-2011-000173. PMid:21917646.

Kaplan, G. S., Patterson, S. H., Ching, J. M., \& Blackmore, C. C. (2014). Why Lean doesn’t work for everyone. BMJ Quality \& Safety, 23(12), 970-973. http://dx.doi.org/10.1136/bmjqs-2014-003248. PMid:25056985.

Laganga, L. R. (2011). Lean service operations: reflections and new directions for capacity expansion in outpatient clinics. Journal of Operations Management, 29(5), 422-433. http://dx.doi.org/10.1016/j.jom.2010.12.005.

Lopes, A. P. V. B. V., \& Carvalho, M. M. (2012). Evolução da literatura de inovação em relações de cooperação: um estudo bibliométrico num período de vinte anos. Gestão \& Produção, 19(1), 203-217. http://dx.doi.org/10.1590/S0104-530X2012000100014.

MacFarlane, M. A. (2014). Sustainable competitive advantage for accountable care organizations. Journal of Healthcare Management, 59(4), 263-271. http://dx.doi.org/10.1097/00115514-201407000-00006. PMid:25154124.

Mazzocato, P., Holden, R. J., Brommels, M., Aronsson, H., Bäckman, U., Elg, M., \& Thor, J. (2012). How does lean work in emergency care? A case study of a lean-inspired intervention at the Astrid Lindgren Children's hospital, Stockholm, Sweden. BMC Health Services Research, 12(1), 28. http://dx.doi.org/10.1186/1472-6963-12-28. PMid:22296919.

Mazzocato, P., Savage, C., Brommels, M., Aronsson, H., \& Thor, J. (2010). Lean thinking in healthcare: a realist review of the literature. Quality \& Safety in Health Care, 19(5), 376-382. http://dx.doi.org/10.1136/qshc.2009.037986. PMid:20724397.

Mazzocato, P., Thor, J., Bäckman, U., Brommels, M., Carlsson, J., Jonsson, F., Hagmar, M., \& Savage, C. (2014). Complexity complicates lean: lessons from seven emergency services. Journal of Health Organization and Management, 28(2), 266-288. http://dx.doi. org/10.1108/JHOM-03-2013-0060. PMid:25065114.

Moraros, J., Lemstra, M., \& Nwankwo, C. (2016). Lean interventions in healthcare: do they actually work? A systematic literature review. International Journal for Quality in Health Care, 28(2), 150-165. http://dx.doi.org/10.1093/intqhc/mzv123. PMid:26811118.

Morrow, E., Robert, G., \& Maben, J. (2014). Exploring the nature and impact of leadership on the local implementation of the Productive Ward Releasing Time to Care. Journal of Health Organization and Management, 28(2), 154-176. http://dx.doi.org/10.1108/JHOM01-2013-0001. PMid:25065108.

Naik, T., Duroseau, Y., Zehtabchi, S., Rinnert, S., Payne, R., McKenzie, M., \& Legome, E. (2012). A structured approach to transforming a large public hospital emergency department via lean methodologies. Journal for Healthcare Quality, 34(2), 86-97. http://dx.doi. org/10.1111/j.1945-1474.2011.00181.x. PMid:22188582. 
Nelson-Peterson, D. L., \& Leppa, C. J. (2007). Creating an environment for caring using lean principles of the Virginia Mason Production System. The Journal of Nursing Administration, 376), 287-294. http://dx.doi.org/10.1097/01.NNA.0000277717.34134. a9. PMid:17563521.

Papadopoulos, T., Radnor, Z., \& Merali, Y. (2011). The role of actor associations in understanding the implementation of Lean thinking in healthcare. International Journal of Operations \& Production Management, 31(2), 167-191. http://dx.doi.org/10.1108/01443571111104755.

Proudlove, N., Moxham, C., \& Boaden, R. (2008). Lessons for lean in healthcare from using six sigma in the NHS. Public Money \& Management, 28(1), 27-34. http://dx.doi.org/10.1111/j.1467-9302.2008.00615.x.

Radnor, Z. J., Holweg, M., \& Waring, J. (2012). Lean in healthcare: The unfilled promise? Social Science \& Medicine, 74(3), 364-371. http://dx.doi.org/10.1016/j.socscimed.2011.02.011. PMid:21414703.

Seidl, K. L., \& Newhouse, R. P. (2012). The intersection of evidence-based practice with 5 quality improvement methodologies. Journal of Nursing Administration, 42(6), 299-304. http://dx.doi.org/10.1097/NNA.0b013e31824ccdc9. PMid:22617691.

Toussaint, J. (2009). Writing the new playbook for U.S. health care: lessons from Wisconsin. Health Affairs, 28(5), 1343-1350. http:// dx.doi.org/10.1377/hlthaff.28.5.1343. PMid:19738250.

Van Lent, W. A. M., Sanders, E. M., \& Van Harten, W. H. (2012). Exploring improvements in patient logistics in Dutch hospitals with a survey. BMC Health Services Research, 12(1), 232. http://dx.doi.org/10.1186/1472-6963-12-232. PMid:22852880.

Vats, A., Goin, K. H., \& Fortenberry, J. D. (2011). Lean analysis of a pediatric intensive care unit physician group rounding process to identify inefficiencies and opportunities for improvement. Pediatric Critical Care Medicine, 12(4), 415-421. http://dx.doi.org/10.1097/ PCC.0b013e3181fe2e3c. PMid:20975612.

Vats, A., Goin, K. H., Villarreal, M. C., Yilmaz, T., Fortenberry, J. D., \& Keskinocak, P. (2012). The impact of a lean rounding process in a pediatric intensive care unit*. Critical Care Medicine, 40(2), 608-617. http://dx.doi.org/10.1097/CCM.0b013e318232e2fc. PMid:21983366.

Waring, J. J., \& Bishop, S. (2010). Lean healthcare: rhetoric, ritual and resistance. Social Science \& Medicine, 71(7), 1332-1340. http:// dx.doi.org/10.1016/j.socscimed.2010.06.028. PMid:20702013.

Wilson, G. (2009). Implementation of releasing time to care: the productive ward. Journal of Nursing Management, 17(5), 647-654. http://dx.doi.org/10.1111/j.1365-2834.2009.01026.x. PMid:19575723.

Young, T. P., \& McClean, S. l. (2008). A critical look at Lean Thinking in healthcare. Quality \& Safety in Health Care, 17(5), $382-386$. http://dx.doi.org/10.1136/qshc.2006.020131. PMid:18842980. 